mgr inż. Mariusz Far

mgr inz. Wojciech Jakuszko

mgr inz. Jarostaw Czerwiński

Instytut Pojazdów Szynowych ,TABOR”

\title{
Arrangement of rail coach interior adjusted for the passengers with reduced mobility, according to the location of the passenger wheelchair in the coach
}

Taking into account Poland's obligation to meet the requirements of the Directive 2008/57/WE related to railways two existing conceptions of the passenger cars (157 Aa and 167A) are presented that meet the Directive criteria. The differences in the interior arrangement are depicted, according to the adopted way of boarding a passenger on the wheelchair. Attention was paid to necessary infrastructure preparation with a view to make use of full opportunities provided by both coaches.

\section{Układ wnętrza wagonów osobowych przystosowanych do przewozu osób o ograniczonej zdolności poruszania się, w zależności od umieszczenia wózka w wagonie}

\begin{abstract}
W zwiazku ze zobowiqzaniem Polski do stosowania wymagań Dyrektywy 2008/57/WE dotyczacej kolei przedstawiono dwie istniejace koncepcje wagonów osobowych (serii 157Aa i 167A) spetniajacych kryteria tej Dyrektywy. Przedstawiono różnice w uktadzie wnętrza w zależności od przyjętego sposobu wprowadzenia podróżnego na wózku inwalidzkim do wagonu. Zwrócono uwage na konieczność przygotowania infrastruktury do wykorzystania w petni możliwości oferowanych przez oba wagony.
\end{abstract}

\section{WSTĘP}

Polska jest zobligowana do stosowania w każdym aspekcie związanym z koleja, wymagań Dyrektywy 2008/57/WE [1] w sprawie interoperacyjności systemu kolei we Wspólnocie Europejskiej.

Ustawa o transporcie kolejowym z dnia 28 marca 2003 r. (tekst jednolity: Dz. U. 2007 r. Nr 16, poz. 94 z późn. zm. [3]) dostosowuje polskie prawo do unijnej dyrektywy dotyczącej interoperacyjności systemu kolei we Wspólnocie, czyli europejskiego projektu, który ma poprawić konkurencyjność sektora kolejowego w stosunku do innych rodzajów transportu. Ustawa ta jest podstawą do dopuszczenia do eksploatacji pojazdów szynowych w Polsce i dostosowuje polskie prawo do unijnej dyrektywy dotyczącej interoperacyjności systemu kolei we Wspólnocie, czyli europejskiego projektu, który ma poprawić konkurencyjność sektora kolejowego w stosunku do innych rodzajów transportu.

Nowe wymagania technicznych specyfikacji interoperacyjności (TSI) systemu kolei we Wspólnocie Europejskiej zaczęły obowiązywać 1 stycznia 2015, a

\section{INTRODUCTION}

Poland is obliged to apply the provisions of the Directive 2008/57/EC [1] in all the railway-related aspects in order to achieve interoperability of the European Community railway system.

The Law on the rail transport of March 28, 2003 (the uniform text in Journal of Laws of 2007, No 16, item 94, as amended [3]) aligns the Polish law with the Union Directive related to interoperability of railway system in the Community. The Directive is an European project aimed at improving competitiveness of the railway sector as compared to the others transport modes.

New requirements of the Technical Specification for Interoperability (TSI) of railway system of the European Community entered into effect on January 1, 2015 , and the changes related to the requirements and to the scope of activities resulting from the Committee decision of December 21, 2007 [1], belong to the most important ones. 
zmiany zarówno w aspekcie wymagań jak i zakresu działalności dotyczące Decyzji Komisji z dnia 21 grudnia 2007 r [1] są jednymi z najistotniejszych.

Zmiany te dotyczą technicznej specyfikacji interoperacyjności w zakresie aspektu „Osoby o ograniczonej możliwości poruszania się" transeuropejskiego systemu kolei konwencjonalnych i transeuropejskiego systemu kolei dużych prędkości. Została ona zastąpiona przez Rozporządzenie Komisji (UE) nr 1300/2014 z dnia 18 listopada 2014 r. w sprawie technicznych specyfikacji interoperacyjności odnoszących się do dostępności systemu kolei Unii dla osób niepełnosprawnych i osób o ograniczonej możliwości poruszania się [2].

Zasadnicze wymagania $\mathrm{w}$ omawianej TSI dotyczące podsystemu „tabor” obejmują:

- siedzenia

- miejsca na wózki inwalidzkie

- drzwi

- oświetlenie

- toalety

- przejścia

- informacje dla pasażerów

- zmiany wysokości

- poręcze

- przedziały do spania dostępne dla osób na wózkach inwalidzkich

- położenie stopnia przy wsiadaniu do pociagu i wysiadaniu z niego

- urządzenia wspomagające wsiadanie.

\section{WYMAGANIA MAJĄCE ISTOTNY WPLYW NA UKLAD WNĘTRZA WAGONU}

Najważniejsze wymagania wynikające z Rozporządzenia 1300/2014 [2] wpływające na konfiguracje wagonu są następujące:

a) Miejsca na wózki inwalidzkie

$\mathrm{Z}$ powyższego wynika, że w składzie lokomotywa +1 wagon typu $Z$ o długości $26400 \mathrm{~mm}$ wymagane jest 1 miejsce na wózek inwalidzki. W składzie lokomotywa +2 do 7 wagonów typu $Z$ wymagane są 2 miejsca na wózki.

b) Obok każdego miejsca na wózek lub naprzeciwko niego musi znajdować się przynajmniej jedno siedzenie dla osoby towarzyszącej osobie korzystającej z wózka. Siedzenie to musi oferować taki sam komfort jak inne siedzenia i może także być umieszczone po przeciwnej stronie korytarza.

c) Co najmniej $10 \%$ miejsc siedzących w każdym zespole trakcyjnym lub pojedynczym pojeździe oraz w każdej klasie musi być oznaczone jako miejsca uprzywilejowane, przeznaczone dla osób niepełnosprawnych i osób o ograniczonej
The changes are connected to the Technical Specification for Interoperability relating to the item "The persons with reduced mobility" in conventional transEuropean railway system and trans-European highspeed railway system. The Specification has been replaced with Commission Regulation (EU) No 1300/2014 of November 18, 2014, concerning the Technical Specification for Interoperability relating to accessibility of the Union railway system for the people with disabilities and the persons with reduced mobility [2].

Principal requirements of the considered TSI and related to the "rolling stock subsystem" include:

[1] seats;

[2] wheelchair spaces;

[3] doors;

[4] lighting;

[5] passages;

[6] passenger information;

[7] floor height changes;

[8] handrails;

[9] sleeping compartments accessible for the persons on wheelchairs;

[10]tilting the step while getting on and off the train;

[11]boarding assistance devices.

\section{THE REQUIREMENTS SIGNIFICANTLY AFFECTING THE COACH INTERIOR AR- RANGEMENT}

The most important requirements resulting from the Regulation No 1300/2014 [2] and affecting the coach configuration are as follows:

a) The wheelchair spaces

Tabela. 1. Minimalna liczba miejsc na wózki inwalidzkie w zależności od długości jednostki [2]

Table 1. Minimum number of wheelchair spaces according to the train length [2]

\begin{tabular}{|c|c|c|}
\hline L.p. & $\begin{array}{c}\text { Długość jednostki } \\
\text { (wylączając } \\
\text { lokomotywę) } \\
\text { The train length } \\
\text { (locomotive excluded) }\end{array}$ & $\begin{array}{c}\text { Liczba miejsc na wózki } \\
\text { wg 1300/2014 } \\
\text { Number of the } \\
\text { wheelchair spaces } \\
\text { according to 1300/2014 }\end{array}$ \\
\hline 1. & Mniejsza niż 30 metrów & 1 miejsce na wózki \\
\hline 2. & 30 do 205 metrów & 2 miejsca na wózki \\
\hline 3. & 205 do 300 metrów & 3 miejsca na wózki \\
\hline 4. & większa niż 300 metrów & 4 miejsca na wózki \\
\hline
\end{tabular}

The above data show that a set including locomotive and one Z-type rail coach 26400 $\mathrm{mm}$ long should include one wheelchair 
możliwości poruszania się.

Miejsca uprzywilejowane zajmują więcej miejsca $\mathrm{w}$ wagonie niż miejsca standardowe. Na przykład przedział dla osób uprzywilejowanych w wagonie typu 167A jest o $100 \mathrm{~mm}$ dłuższy od standardowego.

d) Obok miejsca na wózek inwalidzki należy zapewnić miejsce na obrót o minimalnej średnicy $1500 \mathrm{~mm}$, a także w innych miejscach, w których wózki inwalidzkie mają się obracać o $180^{\circ}$. Miejsce na wózek może być częścią koła przeznaczonego na obrót.

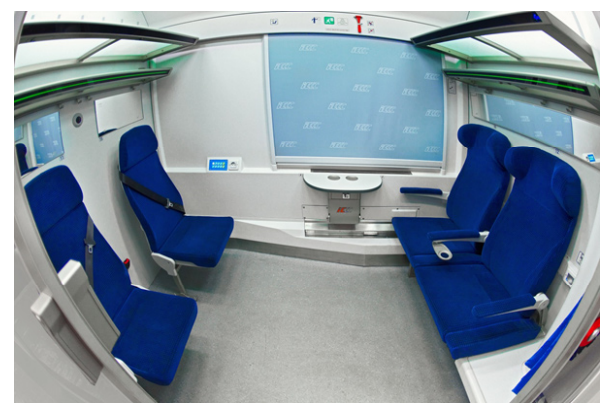

Rys. 1. Wagon 167A - Przedział z miejscami dla osób podróżujących na wózku inwalidzkim (po lewej, po złożeniu foteli) wraz z osobami towarzyszącymi (po prawej). Źródło: własne

Fig. 1. The 167A rail coach - the compartment designed for the wheelchair passengers (at left-hand side - with folded passenger seats) together with their accompanying persons (at right-hand side), source - own materials

e) Jeżeli pociąg jest wyposażony w toalety, należy zapewnić toaletę uniwersalną dostępną z miejsca dla wózków inwalidzkich.

f) Drzwi wewnętrzne przystosowane do wjazdu wózkiem muszą mieć dostępną szerokość użytkową nie mniejszą niż $800 \mathrm{~mm}$.

g) Drzwi w wagonie 167A do przedziału dla podróżujących na wózku inwalidzkim mają szerokość użytkową o ponad $300 \mathrm{~mm}$ większą niż drzwi do przedziału standardowego. space. On the other hand, in case of locomotive and 2 to 7 Z-type rail coaches two wheelchair spaces are required.

b) At least one seat should be available for a person accompanying the wheelchair user, either adjacent to or facing to the wheelchair space. This seat shall offer the same level of comfort as other seats, and may also be located on the opposite side of the corridor.

c) At least 10 percent of the seats located in every articulated train or separate vehicle, as well as in each class, must be marked as privileged seats designed for disabled persons and the persons of reduced mobility.

The privileged seats take up more space than the standard ones. For example - the compartment for privileged persons in the 167A rail coach is $100 \mathrm{~mm}$ longer than the standard one.

d) A turning space, with a minimum diameter of $1500 \mathrm{~mm}$, should be provided adjacent to the wheelchair space for the disabled person in the reference wheelchair to turn the wheelchair around. The wheelchair space may a be part of the turning circle.

e) If the train is equipped with toilets, an universal toilet should be provided, available from the wheelchair space.

f) The interior door made available for wheelchair passengers should be at least $800 \mathrm{~mm}$ wide.

g) The door of the $167 \mathrm{~A}$ rail coach leading to the wheelchair passenger compartment has the useable width exceeding the one of the standard compartment door by $300 \mathrm{~mm}$.

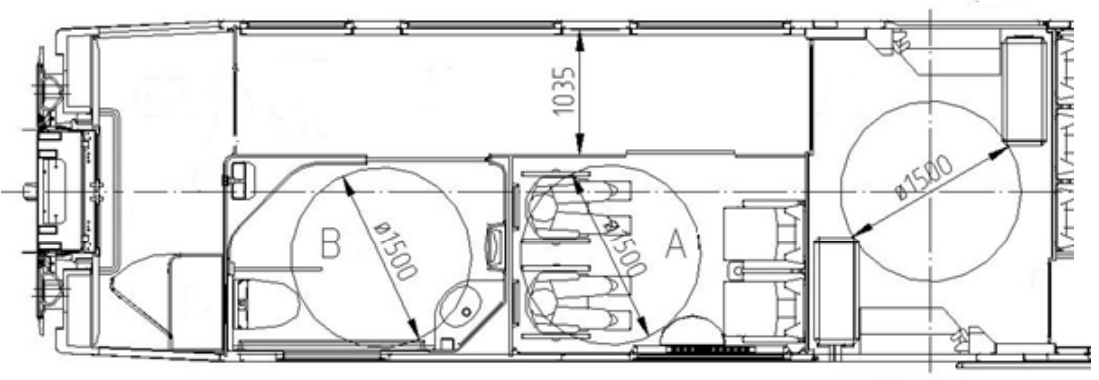

Rys. 2. Wagon 157Aa - Rozplanowanie przestrzeni przeznaczonej dla podróżnych na wózku inwalidzkim: A - Przedział dla podróżnych; B toaleta uniwersalna. Źródło: własne

Fig. 2. The 157Aa rail coach - arrangement of the space for the wheelchair passengers: A - passenger compartment; B - universal toilet, source - own materials
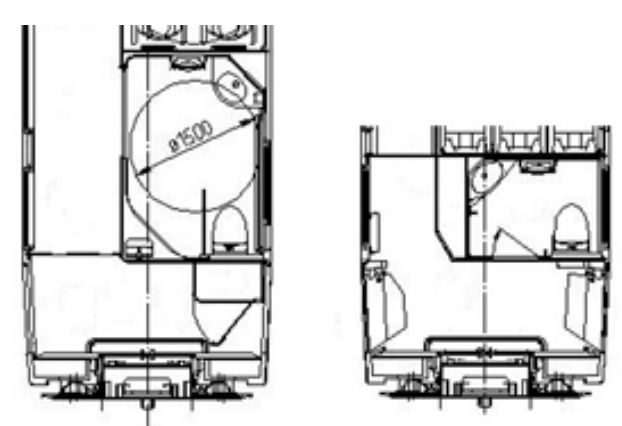

Rys. 3. Porównanie zajmowanej w wagonie przez toaletę przystosowaną dla podróżnych na wózku inwalidzkim (góra) z toaletą standardową wagonu typu Z. Źródło: własne

Fig. 3. Comparison of the coach space designed for the toilet adjusted for wheelchair passengers (top) to the standard Z-type coach toilet, source - own materials 


\section{URZĄDZENIA WSPOMAGAJĄCE WSIA- DANIE}

Spełnienie powyższych wymagań ma sens jedynie wtedy, kiedy umożliwimy sprawny i bezpieczny wjazd pasażera podróżującego na wózku inwalidzkim do wagonu. Rozporządzenie 1300/2014 [2] przewiduje trzy urządzenia umożliwiające wsiadanie pasażera na wózku do pojazdu kolejowego:

- ruchomy stopień i ruchoma platforma

- rampa do wsiadania

- podnośniki pokładowe

Wysokość podłogi w wagonie osobowym wynosząca $1255 \mathrm{~mm}$ nad poziom główki szyny (pgs) sprawia, że najmniejsza różnica poziomów pomiędzy podłogą a powierzchnią peronu na liniach PKP PLK $(960 \mathrm{~mm}$ nad pgs) wynosi $295 \mathrm{~mm}$. Pokonanie przez podróżnego na wózku inwalidzkim tej różnicy poziomów nie jest możliwe przy zastosowaniu pierwszego z urządzeń przewidywanych przez TSI czyli ruchomego stopnia lub platformy. Cel ten można osiagnąć stosując jedynie urządzenia które zdefiniowane są następująco:

a) Rampe do wsiadania, czyli urządzenie, które ustawia się między progiem drzwi pojazdu a peronem. Urządzenie to może być obsługiwane ręcznie, półautomatycznie lub być całkowicie automatyczne.[2]

lub

b) Podnośnik pokładowy, czyli zintegrowane $\mathrm{z}$ drzwiami pojazdu, które musi być w stanie pokonać maksymalną różnicę wysokości między podłoga pojazdu a peronem stacji, na której jest używane.[2]

Porównując budowę i konfigurację wagonów przystosowanych do stosowania jednego z tych urządzeń okazuje się, że wybór urządzenia umożliwiającego wjazd podróżnego na wózku inwalidzkim ma największy wpływ na układ ich wnętrza.

\section{PORÓWNANIE UKLADU WNĘTRZA WA- GONÓW SERII 157Aa i 167A.}

W odpowiedzi na wynikające $\mathrm{z}$ powyższych wymagań zapotrzebowanie przewoźników kolejowych Fabryka Pojazdów Szynowych H. Cegielski w Poznaniu we współpracy z Instytutem Pojazdów Szynowych TABOR w Poznaniu wyprodukowała przedziałowe wagony osobowe 2 klasy typu Z1 z klimatyzacją o oznaczeniu serii 157Aa (w roku 2012) oraz 167A (2014 r.). Są one przystosowane do przewozu osób niepełnosprawnych na wózkach inwalidzkich. Każdy z nich posiada zgodny z Rozporządzeniem 1300/2014 [2] przedział do podróżowania dwóch osób na wózkach inwalidzkich wraz $\mathrm{z}$ opiekunami oraz toaletę przystosowaną do korzystania przez podróżnych na wózku.

\section{BOARDING ASSISTANCE DEVICE}

Fulfillment of the above requirements makes only sense when safe and effective boarding of the wheelchair user is ensured. The Regulation 1300/2014 [2] provides three devices for boarding a wheelchair passenger to the rail coach:

- moveable step and platform

- boarding ramp

- mobile boarding platform

The floor height of a passenger coach is equal to 1255 $\mathrm{mm}$ above the rail head level (rhl) and, in consequence, minimum difference in the levels of platform and coach floor at the PKP PLK lines $(960 \mathrm{~mm}$ above rhl) is equal to $295 \mathrm{~mm}$. A wheelchair passenger is unable to overcome such a level difference using the first of the TSI provided devices, i.e. the moveable step or platform. This can be achieved only with the use of the following devices:

a) A boarding ramp, i.e. a plate located between the vehicle door threshold and the platform. It can be operated manually, semi-automatically or automatically [2].

or

b) A mobile boarding platform, i.e. a lift platform integrated with the vehicle door, able to overcome the level difference at the station where it is used [2].

Comparison of the structure and configuration of the rail coaches adjusted for use of any of these devices shows that the choice of a system enabling access of wheelchair passengers affects the most the coach interior arrangement.

\section{COMPARISON OF INTERIOR ARRANGE- MENT OF THE 157Aa and 167 A RAIL COACHES}

In order to meet the demand of the rail carriers, resulting from the above requirements the H. Cegielski Rail Vehicles Factory in Poznan in cooperation with the Institute of Rail Vehicles TABOR in Poznan manufactured the corridor passenger $2^{\text {nd }}$ class coaches of $\mathrm{Z} 1$ type, with air conditioning, marked as 157Aa (in 2012) and 167A (in 2014). They are designed to carry disabled persons on wheelchairs. Each model is provided with a compartment suitable for two wheelchair passengers together with their attendants, and with a toilet designed to be used by the wheelchair users.

The 167A coach is equipped with a boarding ramp from RAWAG Company.

The 167A rail coach is fitted with a mobile boarding platform, commonly called a lift, from U-lift - a Swedish Company. 
Wagon serii 167A wyposażony jest w rampe do wsiadania produkcji firmy RAWAG.

Wagon serii 167A wyposażony jest w podnośnik pokładowy zwany potocznie windą produkcji szwedzkiej firmy U-lift.

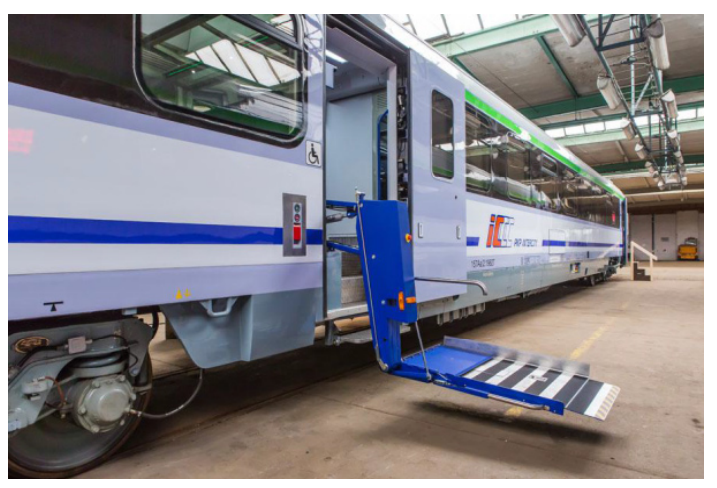

Rys. 5. Wagon 157Aa - winda rozłożona. Źródło: własne

Fig. 5. The 157Aa rail coach - the lift unfolded, source - own materials

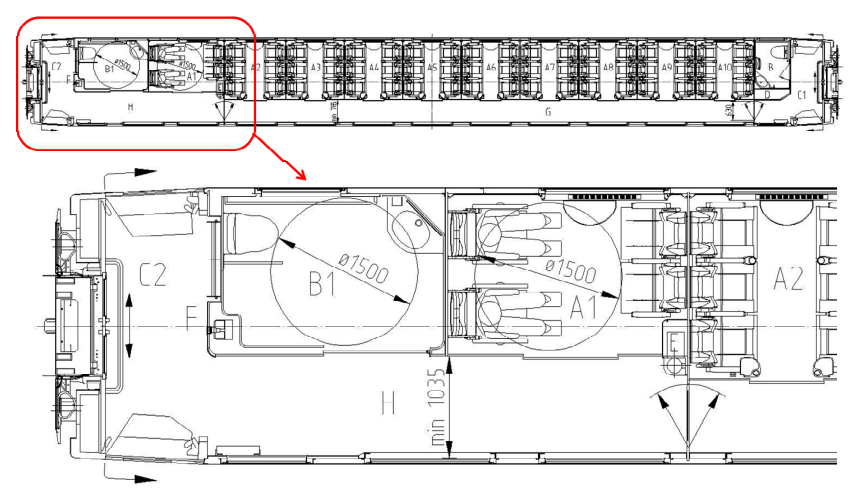

Rys. 7. Wagon 167A. Rozplanowanie wagonu i przestrzeni dla podróżnego na wózku. Źródło: własne

Fig. 7. The $167 \mathrm{~A}$ rail coach - arrangement of the coach interior and the wheelchair passenger space, source - own materials

Analizując powyższe zestawienie można zauważyć, że ze względu na większe zapotrzebowanie na przestrzeń przez pasażerów podróżujących na wózku inwalidzkim istotnie zmniejsza się pojemność wagonu. Różnica ta jest większa dla wagonu 157Aa wyposażonego w windę. W zamian możliwa jest eksploatacja tego wagonu na liniach o peronach 300 a także nie wymaga użycia siły fizycznej (do pomocy podróżnemu przy wjeździe po rampie). Warto również zauważyć, że konstrukcja wagonu 167A wyposażonego w rampe jest bardzo zbliżona do klasycznego wagonu 2 klasy typu Z1. Natomiast układ wnętrza jak i konstrukcja ustroju nośnego wagonu 157Aa są zdecydowanie odmienne. Różnice w budowie ustroju nośnego obrazuje poniższa ilustracja.

\section{Zakończenie}

Każde z prezentowanych rozwiązań ma swoje wady i zalety. Oba wagony spełniają wymagania Rozporządzenia 1300/2014 [2] lecz w inny sposób. Niezbędna

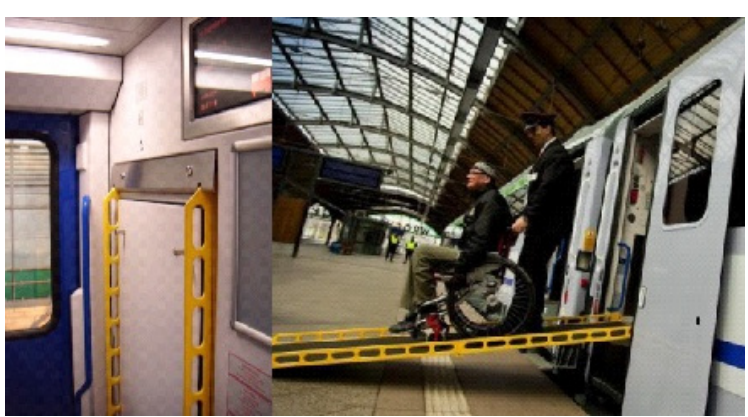

Rys. 4. Wagon 167A - Rampa do wsiadania złożona oraz w użyciu. Źródło: własne

Fig. 4. The 167A rail coach - a boarding ramp, folded and ready for use, source - own materials

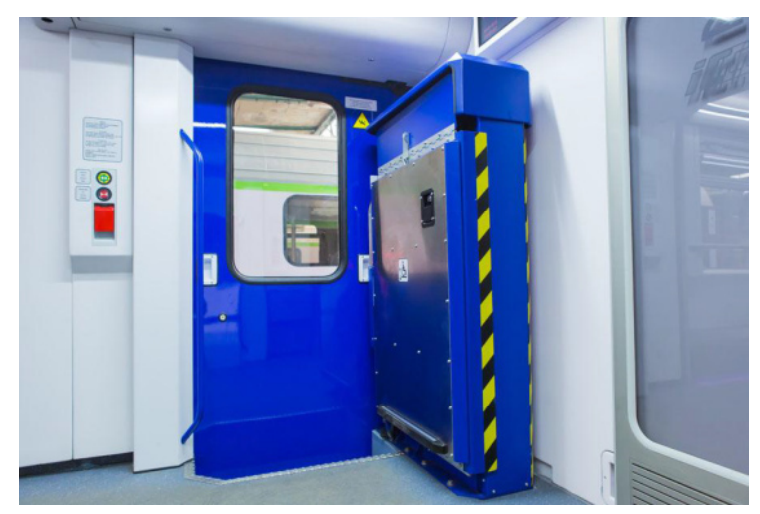

Rys. 6. Wagon 157Aa winda złożona. Źródło: własne Fig. 6. The 157Aa rail coach - the lift folded, source - own materials

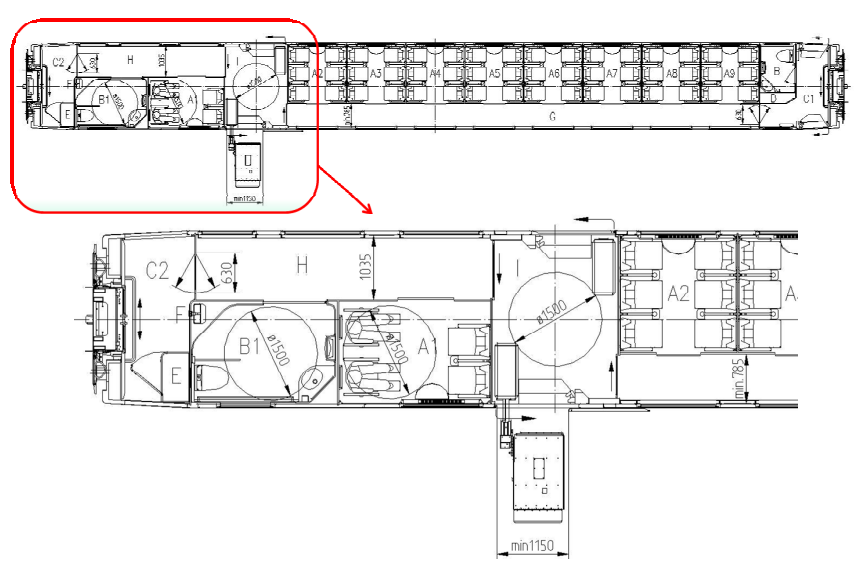

Rys. 8. Wagon 157Aa. Rozplanowanie wagonu i przestrzeni dla podróżnego na wózku.Źródło: własne

Fig. 8. The 157Aa rail coach. Arrangement of the coach interior and the wheelchair passenger space, source - own materials

It can be noticed that due to large space necessary for the wheelchair persons the passenger coach capacity significantly decreases. The capacity reduction is larger in case of the 157Aa rail coach provided with a lift. However, this coach may be used at the railway lines having the platforms only $300 \mathrm{~mm}$ high, furthermore, no physical strength is necessary as in case of the ramp. It should be also noted that the 167A coach design provided with a ramp is very similar to the one of classical 2-class Z1-type rail coach. On the 
Table 2. Comparison of the interior arrangement and key parameters of the boarding assistance devices in the 157Aa and $167 \mathrm{~A}$ rail coaches

\begin{tabular}{|c|c|c|}
\hline Compared area & 157Aa rail coach - LIFT & 167A rail coach - RAMP \\
\hline $\begin{array}{l}\text { Access door designed for disabled } \\
\text { passenger }\end{array}$ & $\begin{array}{l}\text { Intended to allow entry of a wheelchair passenger, } \\
\text { the door located between the bogies }\end{array}$ & $\begin{array}{l}\text { Located traditionally at the rail } \\
\text { coach ends }\end{array}$ \\
\hline $\begin{array}{l}\text { Vestibule adapted to allow entry } \\
\text { of a disabled person }\end{array}$ & $\begin{array}{l}\text { Enabled entry with a lift of the width allowing the } \\
\text { turn of a } 1500 \mathrm{~mm} \text { diameter wheelchair between the } \\
\text { lifts }\end{array}$ & $\begin{array}{l}\text { Traditional, with widened corridor } \\
\text { allowing access to the compartment } \\
\text { for disabled people }\end{array}$ \\
\hline Arrangement of the compartments & $\begin{array}{l}\text { In the area of the lift vestibule the compartment } \\
\text { location is changed }\end{array}$ & $\begin{array}{l}\text { Traditional, at one side of the rail } \\
\text { coach }\end{array}$ \\
\hline $\begin{array}{l}\text { Arrangement of the compartments } \\
\text { designed for disabled people }\end{array}$ & The traveler compartment and the toilet are mirrored & \\
\hline $\begin{array}{l}\text { The number of seats (a standard } \\
\text { corridor coach of Z-type in the } \\
\text { B11 version (according to UIC } \\
567-2 \text { ) has } 66 \text { seats) }\end{array}$ & 50 seats +2 wheelchair spaces & 56 seats +2 wheelchair spaces \\
\hline $\begin{array}{l}\text { Degree of operation complexity } \\
\text { and failure rate of the boarding } \\
\text { assistance device }\end{array}$ & $\begin{array}{l}\text { More complicated semi-automatic operation, training } \\
\text { required, the device itself is decidedly more compli- } \\
\text { cated. }\end{array}$ & $\begin{array}{l}\text { Very simple manual operation, } \\
\text { needs physical strength, the device } \\
\text { is practically failure-free }\end{array}$ \\
\hline $\begin{array}{l}\text { Operation and service cost of the } \\
\text { boarding assistance device }\end{array}$ & Periodic maintenance and surveys required & Virtually maintenance free \\
\hline $\begin{array}{l}\text { Mass of the boarding assistance } \\
\text { device }\end{array}$ & $275 \mathrm{kgs}(2 \mathrm{pcs} . / \mathrm{coach})$ & 30kgs (1pc./coach) \\
\hline $\begin{array}{l}\text { Minimum clearance of the access } \\
\text { door }\end{array}$ & $1150 \mathrm{~mm}$ & $800 \mathrm{~mm}$ \\
\hline $\begin{array}{l}\text { Allowable difference between the } \\
\text { platform and rail coach floor } \\
\text { levels }\end{array}$ & $1000 \mathrm{~mm}$ (for platform height $300 \mathrm{~mm}$ ) & $\begin{array}{l}\text { 490mm (for platform height } \\
760 \mathrm{~mm} \text { ) }\end{array}$ \\
\hline $\begin{array}{l}\text { The distance necessary at the } \\
\text { platform (measured from the rail } \\
\text { coach wall) for boarding a wheel- } \\
\text { chair passenger to the vehicle }\end{array}$ & about $2750 \mathrm{~mm}$ & about $3500 \mathrm{~mm}$ \\
\hline
\end{tabular}

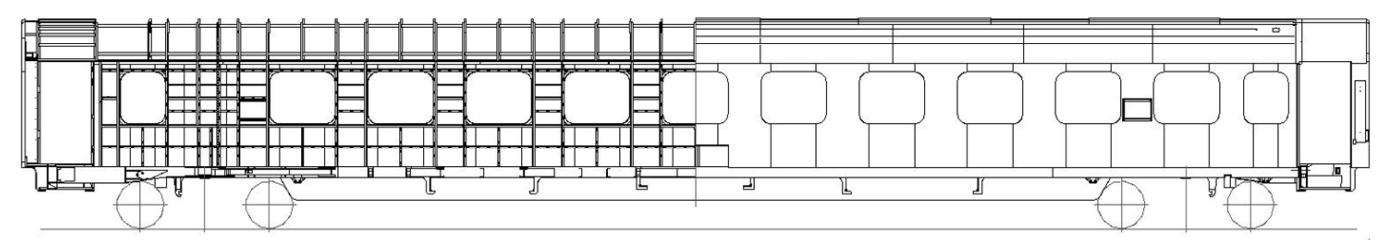

Rys. 9. Wagon 167A. Ustrój nośny. Niemal typowy wagon Z1. Źródło: własne

Fig. 9. The 167A rail coach, load -bearing structure - nearly typical Z1 coach, source - own materials

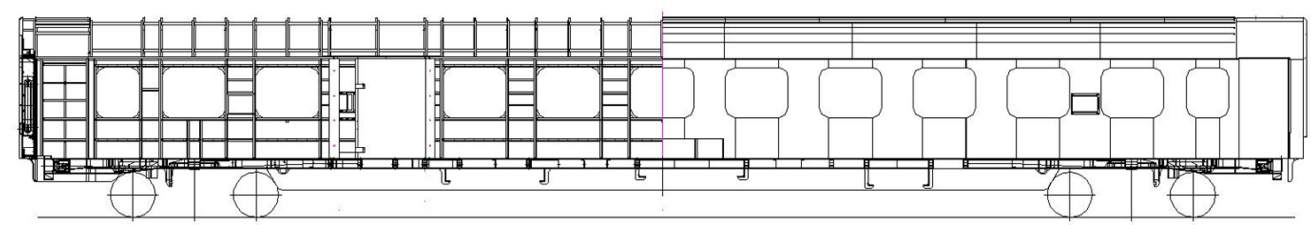

Rys. 10. Wagon 157Aa. Ustrój nośny. Drzwi wejściowe umieszczone pomiędzy wózkami. Źródło: własne

Fig. 10. The 157Aa rail coach, load -bearing structure - the access doors located between the bogies, source - own materials 
Tabela. 2. Porównanie układu wnętrza i kluczowych parametrów urządzenia wspomagającego wsiadanie wagonów serii 157Aa i 167A

\begin{tabular}{|c|c|c|}
\hline Porównywany obszar & Wagon 157Aa - WINDA & Wagon 167A - RAMPA \\
\hline $\begin{array}{l}\text { Drzwi wejściowe przeznaczone dla } \\
\text { inwalidy }\end{array}$ & $\begin{array}{l}\text { Przeznaczone do wjazdu dla osoby na } \\
\text { wózku inwalidzkim umiejscowione } \\
\text { pomiędzy wózkami. }\end{array}$ & $\begin{array}{l}\text { Rozmieszczone tradycyjnie, na skra- } \\
\text { jach wagonów. }\end{array}$ \\
\hline $\begin{array}{l}\text { Przedsionek przeznaczony do wjazdu } \\
\text { przez inwalidę }\end{array}$ & $\begin{array}{l}\text { Zapewniający możliwość wjazdu za } \\
\text { pomocą windy o szerokości zapewnia- } \\
\text { jącej obrót wózka o średnicy } 1500 \mathrm{~mm} \\
\text { pomiędzy windami. }\end{array}$ & $\begin{array}{l}\text { Tradycyjny, z poszerzonym koryta- } \\
\text { rzem umożliwiającym dojazd do prze- } \\
\text { działu dla niepełnosprawnych }\end{array}$ \\
\hline Rozmieszczenie przedziałów & $\begin{array}{l}\text { W rejonie przedsionka } \mathrm{z} \text { windami } \\
\text { następuje zmiana strony położenia } \\
\text { przedziałów. }\end{array}$ & Tradycyjne. Po jednej stronie wagonu \\
\hline $\begin{array}{l}\text { Układ przedziałów przeznaczonych dla } \\
\text { inwalidy }\end{array}$ & \multicolumn{2}{|c|}{ Przedział podróżny i toaleta są odbiciem lustrzanym } \\
\hline $\begin{array}{l}\text { Ilość miejsc siedzących (standardowy } \\
\text { wagon przedziałowy typu Z } \\
\text { w wykonaniu B11 (wg UIC 567-2) } \\
\text { posiada } 66 \text { miejsc) }\end{array}$ & $50+2$ miejsca dla inwalidy & $56+2$ miejsca dla inwalidy \\
\hline $\begin{array}{l}\text { Stopień skomplikowania obsługi } \\
\text { i awaryjność urządzenia wspomagają- } \\
\text { cego wsiadanie }\end{array}$ & $\begin{array}{l}\text { Obsługa półautomatyczna bardziej } \\
\text { skomplikowana, wymagająca prze- } \\
\text { szkolenia - znacznie wyższy stopień } \\
\text { skomplikowania konstrukcji urządze- } \\
\text { nia }\end{array}$ & $\begin{array}{l}\text { Obsługa ręczna, bardzo prosta, wyma- } \\
\text { ga użycia siły fizycznej - urządzenie } \\
\text { praktycznie bezawaryjne }\end{array}$ \\
\hline $\begin{array}{l}\text { Koszt obsługi i serwisowania urządze- } \\
\text { nia wspomagającego wsiadanie }\end{array}$ & $\begin{array}{l}\text { Wymagane okresowe konserwacje i } \\
\text { przeglądy }\end{array}$ & Praktycznie bezobsługowa \\
\hline $\begin{array}{l}\text { Masa urządzenia wspomagającego } \\
\text { wsiadanie }\end{array}$ & 275kg (2szt./wag.) & 30kg (1 szt./wag.) \\
\hline Min. prześwit drzwi wejściowych & $1150 \mathrm{~mm}$ & $800 \mathrm{~mm}$ \\
\hline $\begin{array}{l}\text { Obsługiwana różnica peronów przez } \\
\text { urządzenie wspomagające wsiadanie }\end{array}$ & $1000 \mathrm{~mm}$ (peron 300) & 490mm (peron 760) \\
\hline $\begin{array}{l}\text { Konieczna przestrzeń na peronie } \\
\text { umożliwiająca załadunek osoby nie- } \\
\text { pełnosprawnej na wózku do wagonu } \\
\text { (mierzona od ściany wagonu) }\end{array}$ & ok. $2750 \mathrm{~mm}$ & ok. $3500 \mathrm{~mm}$ \\
\hline
\end{tabular}

jest więc analiza potrzeb wykonana przez użytkownika wagonu aby miał świadomość czym dysponuje, co chce osiagnąc i wtedy dobrać odpowiednie rozwiązanie. Należy pamiętać, że aby podróż osób poruszających się na wózku inwalidzkim mogła przebiegać komfortowo, nie wystarczy spełnić wymagań w obszarze pojazdu. Niezmiernie istotnym jest, aby infrastruktura umożliwiała dostanie się podróżnego na peron a system rezerwacji miejsc powinien gwarantować możliwość zajęcia miejsca przez podróżnego na wózku oraz jego opiekuna.

\section{Literatura}

Bibliography

[1] Decyzja Komisji nr 2008/164/WE z dnia 21 grudnia 2007 r. dotyczaca technicznej specyfikacji interoperacyjności $w$ zakresie aspektu „Osoby o ograniczonej możliwości poruszania się" transeuropejskiego systemu kolei konwencjonalnych i transeuropejskiego systemu kolei dużych prędkości.

[2] Rozporzqdzenie Komisji (UE) nr 1300/2014 z dnia 18 listopada 2014 r. w sprawie technicznych specyfikacji interoperacyjności odnoszacych sie do dostępności systemu kolei Unii dla osób niepetnosprawnych i osób o ograniczonej możliwości poruszania się.

[3] Ustawa z dnia 28 marca 2003 r. o transporcie kolejowym (Dz. U. z 2015 r. poz. 1297). other hand, the interior arrangement and load-bearing structure of the 157Aa rail coach are quite different. The differences in these load-bearing structures are shown in Figs 9 and 10 below.

\section{Conclusions}

Each of the above presented solutions has its advantages and disadvantages. Both rail coaches meet the requirements of the Regulation 1300/2014 [2] but on different ways. Hence, the customer should analyze his/her needs with a view to recognize the goals and available versions. Such analysis shall allow to choose a proper solution. In order to ensure comfortable journey of the wheelchair passengers the fulfillment of the requirements related only to the vehicle area is not sufficient. It is essential to provide the infrastructure allowing the traveler to access the platform and, at the same time, the reservation system should guarantee the wheelchair passenger and the accompanying person to take their seats. 